\title{
Tuning the size of a redox-active tetrathiafulvalene-based self-assembled ring
}

\author{
Sébastien Bivaud, Sébastien Goeb*, Vincent Croué, Magali Allain, Flavia Pop \\ and Marc Sallé
}

\section{Letter}

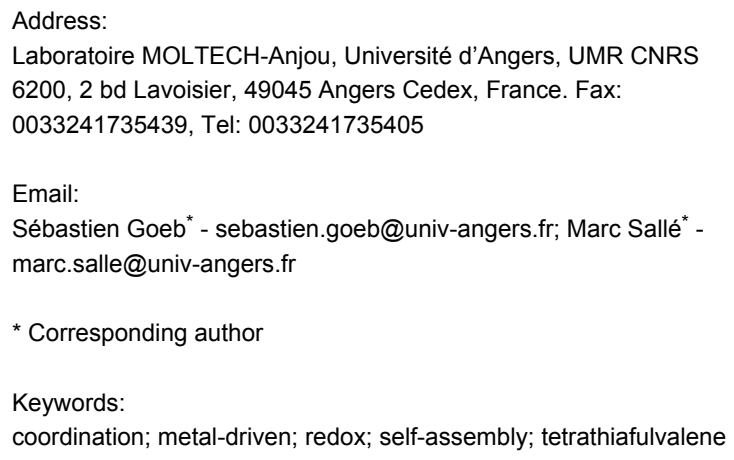

\author{
Beilstein J. Org. Chem. 2015, 11, 966-971. \\ doi:10.3762/bjoc. 11.108 \\ Received: 12 February 2015 \\ Accepted: 07 May 2015 \\ Published: 05 June 2015 \\ This article is part of the Thematic Series "Tetrathiafulvalene chemistry". \\ Guest Editor: P. J. Skabara \\ (C) 2015 Bivaud et al; licensee Beilstein-Institut. \\ License and terms: see end of document.
}

\begin{abstract}
The synthesis of a new Pd coordination-driven self-assembled ring $\mathrm{M}_{6} \mathrm{~L}_{3}$ constructed from a concave tetrapyridyl $\pi$-extended tetrathiafulvalene ligand (exTTF) is described. The same ligand is also able to self-assemble in a $\mathrm{M}_{4} \mathrm{~L}_{2}$ mode as previously described. Herein, we demonstrate that the bulkiness of the ancillary groups in the Pd complex allows for modulating the size and the shape of the resulting discrete self-assembly, which therefore incorporate two $\left(\mathrm{M}_{4} \mathrm{~L}_{2}\right)$ or three $\left(\mathrm{M}_{6} \mathrm{~L}_{3}\right)$ electroactive exTTF sidewalls.
\end{abstract}

\section{Findings}

The coordination-driven approach is a well-established method that has been extensively used to reach more and more sophisticated cage-like discrete molecules [1-19], including redoxactive ones [20]. In this context and since this strategy results from one single chemical step (metal to ligand assembly), there is a great interest in controlling the parameters which govern the final size and geometry of the resulting discrete self-assembled structures. Some general trends have first to be considered: i) as awaited from a lower kinetic stability, the ligand exchange process in the case of square-planar Pd(II) complexes is faster than with $\mathrm{Pt}(\mathrm{II})$ analogues; ii) the most thermodynamically stable species is formed along the assembly process, but if no evident energetic advantage exists for one structure, a dynamic equilibrium between two or more macrocyclic entities may be observed in solution [21-26]. This is in particular the case with flexible (including long) linear ditopic ligands, which favor the formation of triangle species whereas shorter ones shift the equilibrium towards molecular squares for which the enthalpic gain (less steric constraint) compensates for the entropic penalty. Beside the conformational flexibility of the ligand, parameters such as temperature, concentration and solvent type can influence the equilibrium. Isolation of the species from a given equilibrium has not been often carried out [27,28]. We were able in our case to operate the separation of a mixture of a 
triangle and a square [29]. The triangle-square dynamic equilibrium also depends on the nature of the ancillary ligand on the metal corner [21,22,26,30-33]. In particular, steric repulsions due to the ancillary ligand may displace the equilibrium towards the triangular species since the latter offers more space around the metal center. A change in the ancillary group can also lead to a modification of the cavity volume for a given cage [34] Beyond those results, additional important issues still need to be addressed and concern in particular the possibility to obtain, from one given ligand, one single and stable assembly whose cavity size can be controlled.

We recently depicted the preparation and properties of redoxactive rings [29,35] and cages [36-40] integrating the tetrathiafulvalene (TTF) skeleton. In particular, we described selfassembled containers prepared from an electron-rich ligand precursor based on the extended-TTF framework (exTTF) [39].

On this basis, we report herein that the size and the shape of coordination-driven self-assembled redox-active cages, constructed from a exTTF-based tetratopic ligand, can be tuned by modulating the bulkiness of the ancillary group on the metal complex precursor.

The tetrapyridyl-exTTF ligand L1 (Scheme 1, Figure 1a) was synthesized through a palladium catalysed $\mathrm{C}-\mathrm{H}$ arylation from the naked exTTF [39]. We already reported that the selfassembly process of this tetratopic ligand with cis$\mathrm{M}(\mathrm{dppf})(\mathrm{OTf})_{2}(\mathrm{M}=\mathrm{Pd}$ or Pt; dppf = 1,1'-bis(diphenylphosphino)ferrocene; OTf $=$ trifluoromethanesulfonate) in nitromethane at $40{ }^{\circ} \mathrm{C}$ converged into a single symmetrical $\mathrm{M}_{4} \mathrm{~L}_{2}$ discrete species (Scheme 1, Figure 1b) [39]. It is worth noting that the through space interaction between the phenyl rings of the bulky 1,1'-bis(diphenylphosphino) ferrocene (dppf) coligand and the pyridine moieties force the exTTF unit to increase significantly its curvature in comparison to ligand L1 ( $56^{\circ}$ vs $86^{\circ}$ respectively between the 1,3-dithiol-2-ylidene mean planes (Figure 1)). This leads to the formation of the compact $\mathrm{M}_{4} \mathrm{~L}_{2}$ assembly in which the pyridyl units are wedged between the dppf units, producing therefore a robust assembly affording an oblate spheroidal cavity. On this basis and considering the relative flexibility of the large exTTF moiety, we assumed that the bulkiness of the metal complex coligand could be adjusted to tune the macrocycle size and shape.

Complexation of ligand L1 with precursor $\mathrm{Pd}(\mathrm{en})(\mathrm{OTf})_{2}$ (en $=1,2$-ethylenediamine) was carried out in DMSO at $40^{\circ} \mathrm{C}$ and monitored by ${ }^{1} \mathrm{H}$ NMR. In $30 \mathrm{~min}$, the reaction converged into a unique symmetrical discrete species that could be isolated in more than $90 \%$ yield after precipitation in ethyl acetate. In contrast with assembly $\mathrm{M}_{4} \mathrm{~L}_{2}$ for which the presence of through-space interactions (Figure $4 \mathrm{a}$ ) between the coligand

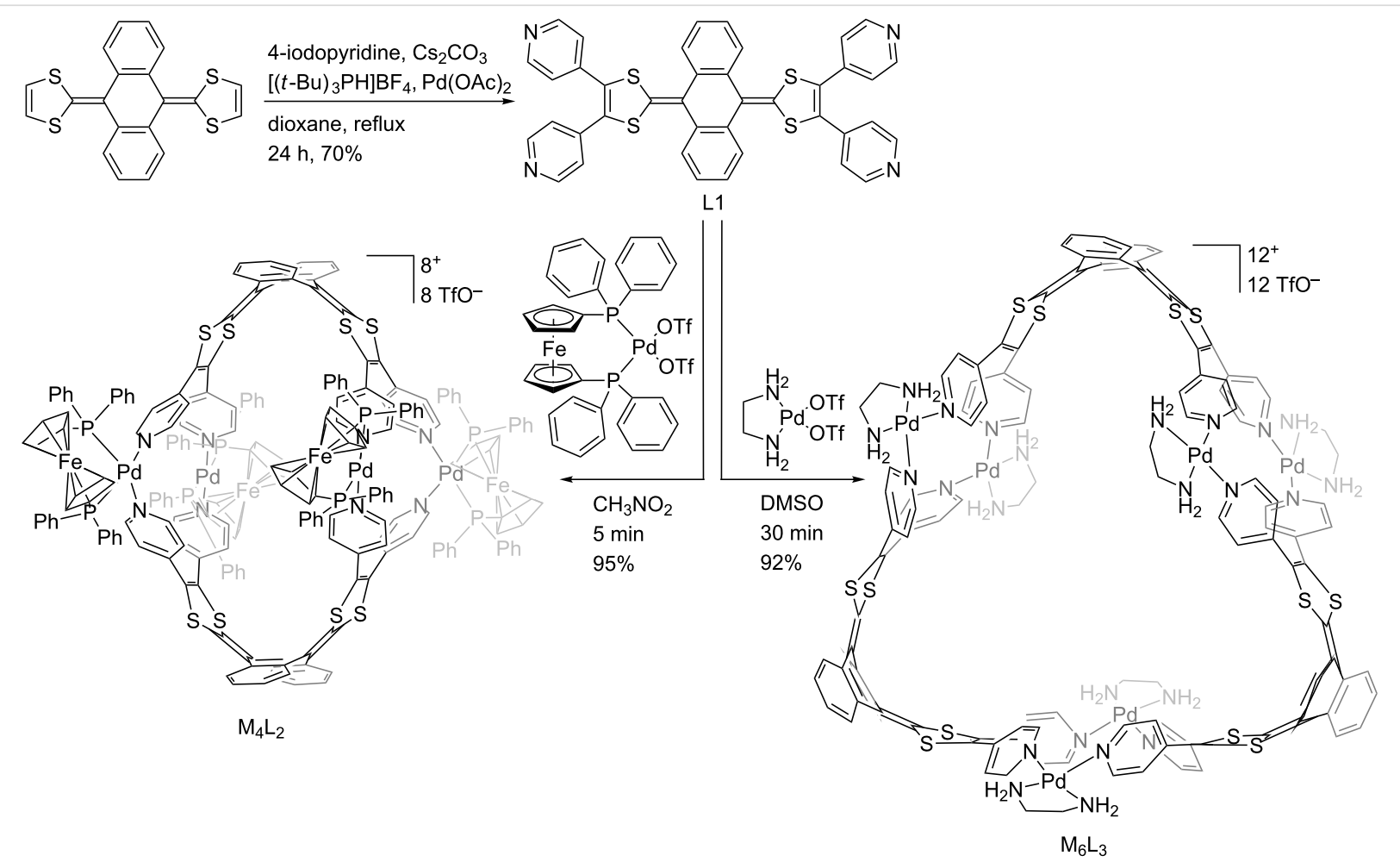

Scheme 1: Synthesis of ligand $L 1$, self-assemblies $M_{4} L_{2}$ and $M_{6} L_{3}$. 


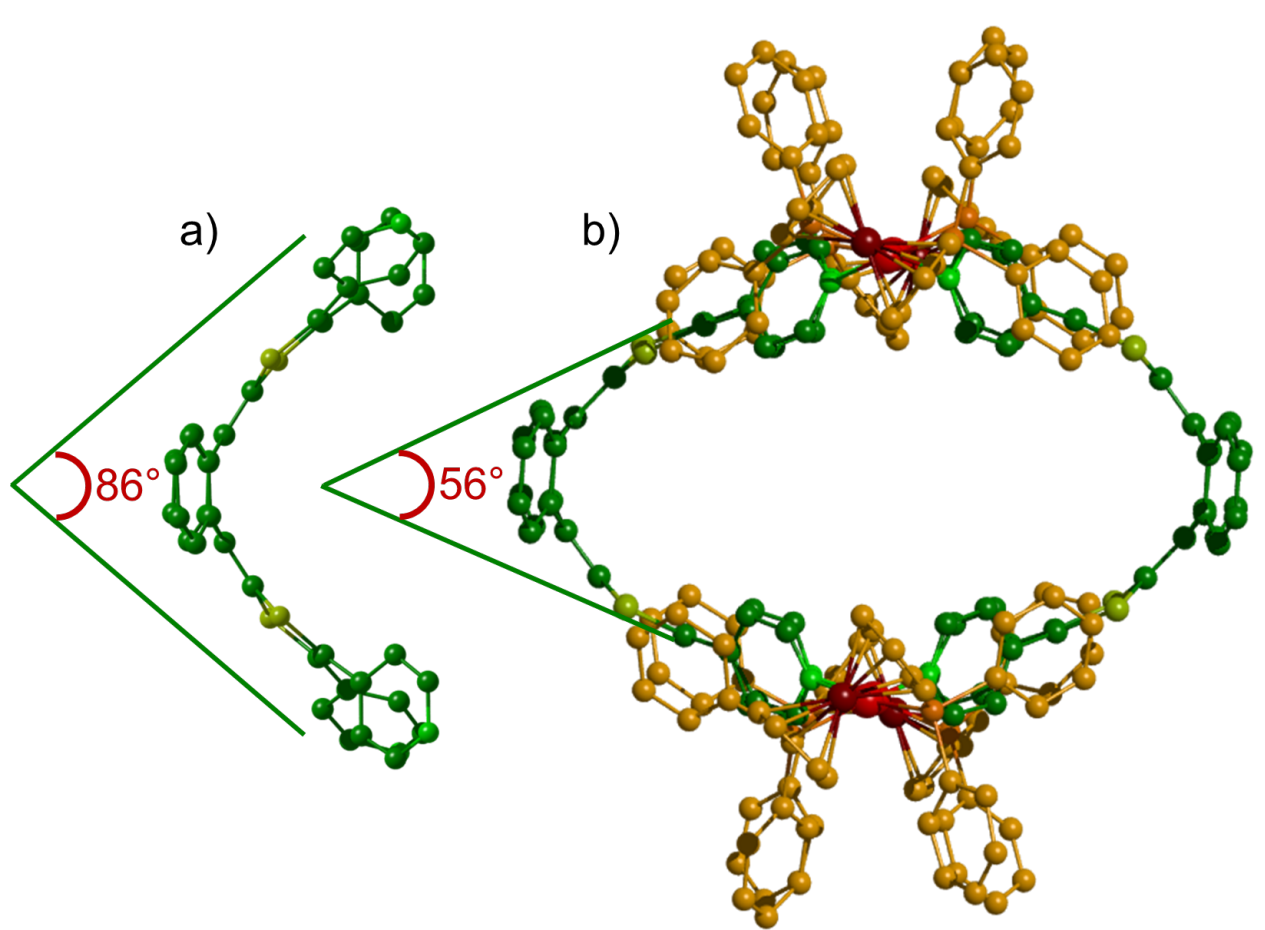

Figure 1: X-ray crystal structures of: (a) ligand $\mathrm{L} 1$, (b) self-assembly $\mathrm{M}_{4} \mathrm{~L}_{2}$. For clarity, $\mathrm{H}$ atoms and $\mathrm{TfO}^{-}$counteranions have been omitted.

phenyl units (dppf) and pyridyl groups result in an upfield shift of their signals (Figure $2 \mathrm{~b}$ ) compared to L1, the pyridyl protons are in this case shifted downfield (Figure 2c), as expected from

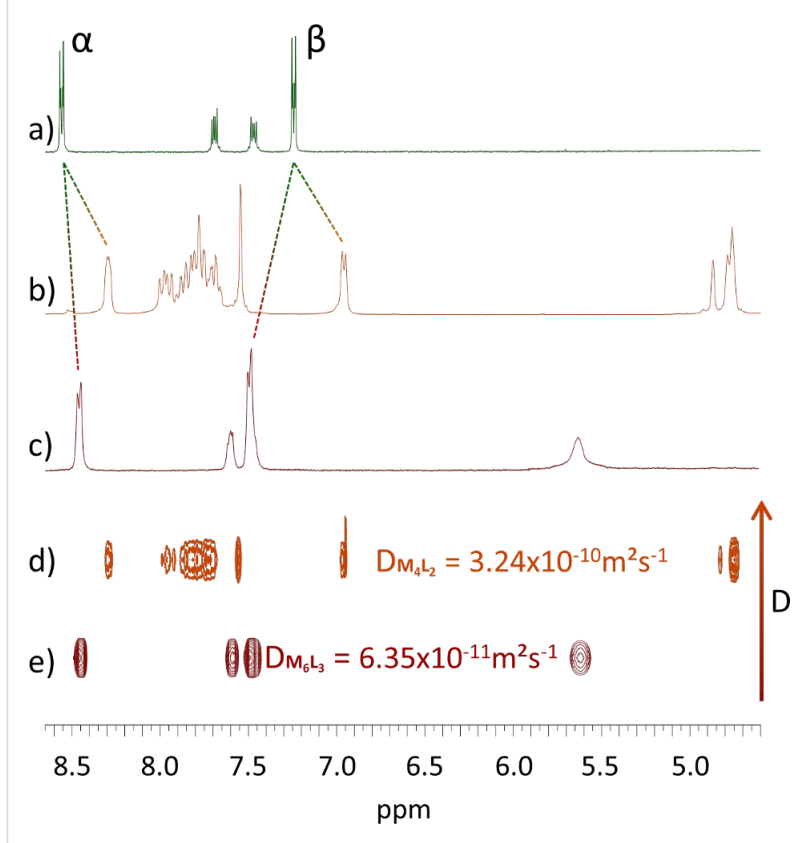

Figure 2: ${ }^{1} \mathrm{H}$ NMR, downfield region ( $\alpha$ and $\beta$ signals correspond respectively to $\alpha$ and $\beta$ pyridyl protons): (a) $L 1$ (DMSO- $d_{6}$ ), (b) $M_{4} L_{2}$ $\left(\mathrm{CD}_{3} \mathrm{NO}_{2}\right)$, (c) $\mathrm{M}_{6} \mathrm{~L}_{3}$ (DMSO- $\left.d_{6}\right)$, (d) DOSY NMR of $\mathrm{M}_{4} \mathrm{~L}_{2}\left(\mathrm{CD}_{3} \mathrm{NO}_{2}\right)$ and (e) DOSY NMR of $M_{6} \mathrm{~L}_{3}\left(\mathrm{DMSO}-\mathrm{d}_{6}\right)$. coordination to a metal center. The corresponding DOSY NMR shows only one alignment of signals and confirms the formation of one unique species diffusing in solution with a $\mathrm{D}$ value of $6.35 \times 10^{-11} \mathrm{~m}^{2} \cdot \mathrm{s}^{-1}$ (Figure $2 \mathrm{e}$ ). An estimated hydrodynamic radius $\left(R_{\mathrm{H}}\right)$ of $17.2 \AA$ could be calculated from the Stokes-Einstein equation $(T=298 \mathrm{~K})$ for this new discrete system [41]. This result indicates that the latter is larger than the already described $\mathrm{M}_{4} \mathrm{~L}_{2}$ container $\left(R_{\mathrm{H}}=10.8 \AA\right.$ (Figure $2 \mathrm{~d}$ )), and that the corresponding size is compatible with the formation of a $\mathrm{M}_{6} \mathrm{~L}_{3}$ assembly (Scheme 1).

ESI-MS mass spectroscopy experiments were carried out in acetone and agree with a $\mathrm{M}_{6} \mathrm{~L}_{3}$ stoichiometry in the gas phase for the new assembly, with multicharged isotopic patterns at $m / z=2278.3,1468.9,1064.4,821.8$, corresponding respectively to $\left[\mathrm{M}_{6} \mathrm{~L}_{3}-10 \mathrm{TfO}^{-}\right]^{2+},\left[\mathrm{M}_{6} \mathrm{~L}_{3}-9 \mathrm{TfO}^{-}\right]^{3+},\left[\mathrm{M}_{6} \mathrm{~L}_{3}-8 \mathrm{TfO}^{-}\right]^{4+}$, $\left[\mathrm{M}_{6} \mathrm{~L}_{3}-7 \mathrm{TfO}^{-}\right]^{5+}$ species and matching perfectly with theoretical ones (Supporting Information File 1, Figure S8).

Single crystals of assembly $\mathrm{M}_{6} \mathrm{~L}_{3}$ were grown by slow diffusion of ethyl acetate in DMSO and allowed for determining unambiguously the solid-state structure by a synchrotron X-ray diffraction study (Figure 3). Whereas the sterically demanding dppf moiety leads to a $\mathrm{M}_{4} \mathrm{~L}_{2}$ structure characterized by i) exTTF moieties which are highly distorted and ii) short interplanar distances between the phenyl units of the ancillary dppf complex and the pyridyl rings (3.5 $\AA$ ) (Figure 4a), a much less 


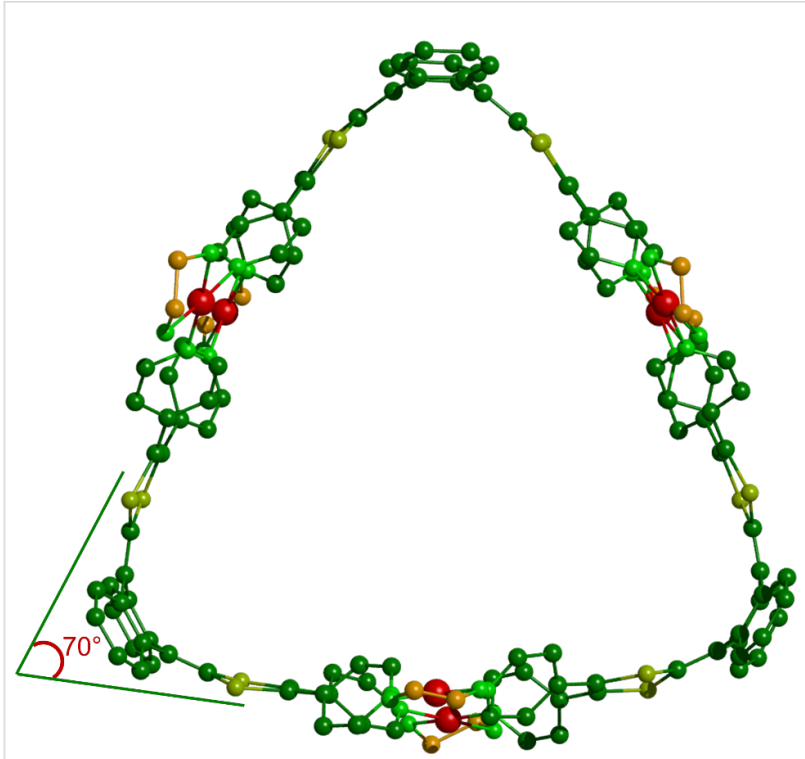

Figure 3: X-ray crystal structure of self-assembly $M_{6} L_{3}$. For clarity, $\mathrm{H}$ atoms and $\mathrm{TfO}^{-}$counteranions have been omitted.

constrained system is observed in the case of the $\mathrm{M}_{6} \mathrm{~L}_{3}$ complex, characterizing a prismatic structure which is not driven by steric effects but which is mainly governed by thermodynamic aspects.
The $\mathrm{M}_{6} \mathrm{~L}_{3}$ assembly forms a trigonal prismatic structure presenting a cavity defined by $17.7 \AA$ high, $19.0 \AA$ edge and $9.5 \AA$ depth. The curvature of the exTTF moiety in the complex ( $70^{\circ}$ between the 1,3-dithiol-2-ylidene mean plans, Figure 3 ) is intermediate between those observed for the free ligand L1 and the ligand in $\mathrm{M}_{4} \mathrm{~L}_{2}$, which illustrates a lower ring constraint than in $\mathrm{M}_{4} \mathrm{~L}_{2}$. In addition to the expected variation of the $N$ (pyridyl)-Pd- $N$ (pyridyl) angle within the distorted square planar - i.e. the dppf complex $\left(\mathrm{M}_{4} \mathrm{~L}_{2}, 86^{\circ}\right)$ and the en one $\left(\mathrm{M}_{6} \mathrm{~L}_{3}, 9^{\circ}\right)$ (Figure 4$)-$, the change in the ancillary ligand also results in a modification of the rotation angles between the pyridyl units and the 1,3-dithiol-2-ylidene heterocycles. Because of the lower steric demand with the 1,2-ethylenediamine co-ligand, the vicinal pyridyl units are free to rotate around the $\mathrm{C}$-pyridine axis in $\mathrm{M}_{6} \mathrm{~L}_{3}$, resulting in dihedral angles of $40^{\circ}$ and $52^{\circ}$ in the crystal (Figure $4 \mathrm{~b}$ ). These values are in the same range as those observed in the free ligand $\mathrm{L} 1\left(35^{\circ}\right.$ and $63^{\circ}$ ). By comparison, the pyridyl units in complex $\mathrm{M}_{4} \mathrm{~L}_{2}$ are tilted with angles of $52^{\circ}$ and $-69^{\circ}$ in the solid (Figure $4 \mathrm{a}$ ). Those higher values result from the increased steric demand generated by the dppf coligand.

A cyclic voltammetry study of prism $\mathrm{M}_{6} \mathrm{~L}_{3}$ was carried out in acetonitrile containing $0.1 \mathrm{M} \mathrm{NBu}_{4} \mathrm{PF}_{6}$ (Figure 5). Compared to ligand L1 which presents the usual electrochemical behavior of
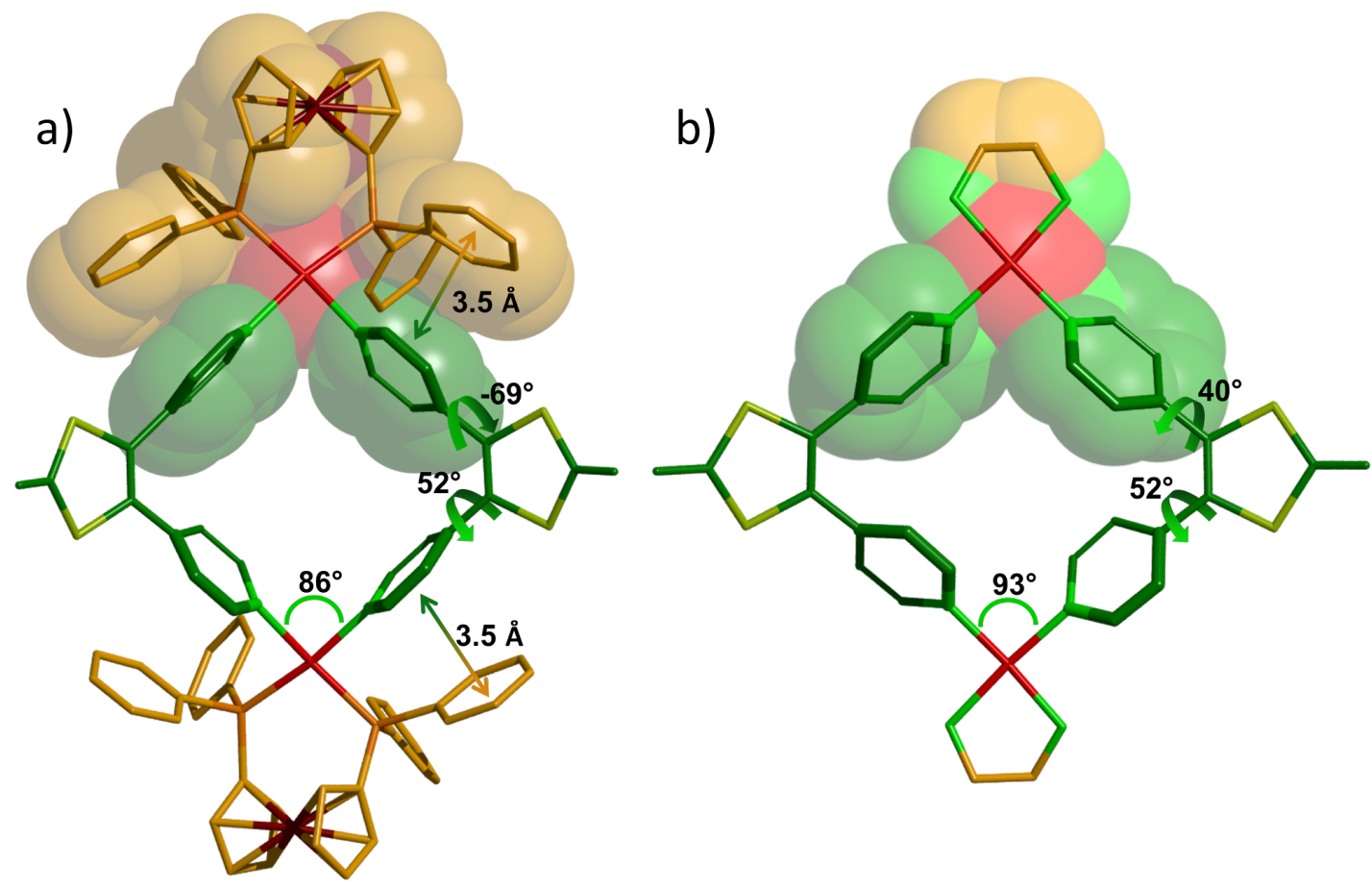

Figure 4: Geometry (from XRD) around two Pd centers in $M_{4} L_{2}$ (a) and $M_{6} L_{3}$ (b). The exTTF moieties have been cut for clarity. 


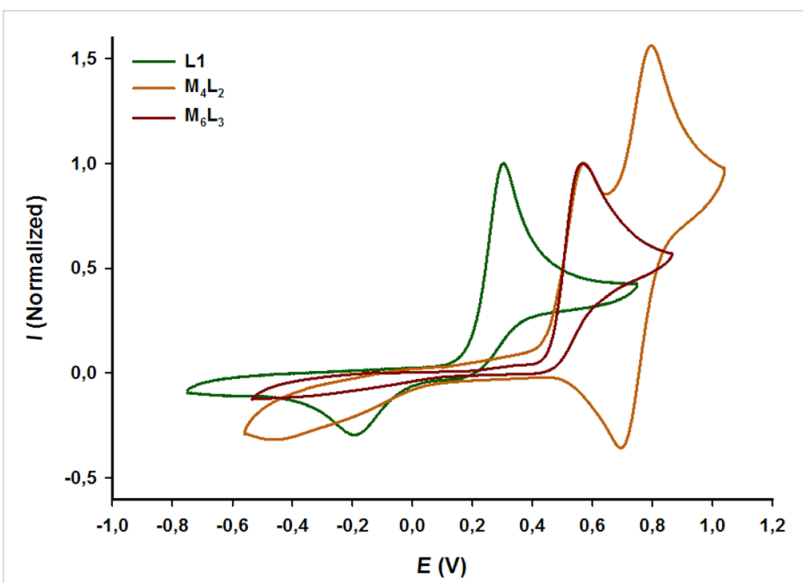

Figure 5: Cyclic voltammogram of $\mathrm{L} 1\left(\mathrm{c}=10^{-3} \mathrm{M}, \mathrm{CH}_{3} \mathrm{CN} / \mathrm{CH}_{2} \mathrm{Cl}_{2}\right.$ (v/v 50/50), $0.1 \mathrm{M} \mathrm{n}-\mathrm{Bu}_{4} \mathrm{NPF}_{6}, 100 \mathrm{mV} \cdot \mathrm{s}^{-1}, \mathrm{Pt}$ ), $\mathrm{M}_{4} \mathrm{~L}_{2}$ and $\mathrm{M}_{6} \mathrm{~L}_{3}$ $\left(c=10^{-3} \mathrm{M}, \mathrm{CH}_{3} \mathrm{CN}, 0.1 \mathrm{M} \mathrm{n}-\mathrm{Bu}_{4} \mathrm{NPF}_{6}, 100 \mathrm{mV} \cdot \mathrm{s}^{-1}, \mathrm{Cgr}\right), \mathrm{V}$ vs $\mathrm{Fc} / \mathrm{Fc}^{+}$

exTTF derivatives, i.e. one poorly electrochemically reversible two-electrons oxidation process, the oxidation of exTTF in selfassembly $\mathrm{M}_{6} \mathrm{~L}_{3}$ is shifted to higher potential $(+0.26 \mathrm{~V})$, which is mainly attributed to the coordination to the Pd center. It can be noted that the redox behavior of $\mathrm{M}_{6} \mathrm{~L}_{3}$ is very similar to the one of $\mathrm{M}_{4} \mathrm{~L}_{2}$ [42], with an irreversible oxidation occurring exactly at the same potential $\left(E_{\mathrm{ox}}=+0.57 \mathrm{~V}\right.$ vs $\left.\mathrm{Fc} / \mathrm{Fc}^{+}\right)$, illustrating the fact that the nature of the ancillary ligand does not impact the electronic properties of exTTF in the corresponding self-assemblies.

In summary, two different coordination-driven discrete selfassemblies varying by the size and the shape can be built from the same tetratopic exTTF-based ligand, simply by changing the ancillary group on the Pd metal center. In particular, whereas a 1,1'-bis(diphenylphosphino)ferrocene co-ligand promotes a clipping of the ligand pyridyl units and leads to a strong curvature of the exTTF moiety integrated in a $\mathrm{M}_{4} \mathrm{~L}_{2}$ coordination cage, the use of a smaller co-ligand leads to the formation of a larger $\mathrm{M}_{6} \mathrm{~L}_{3}$ cavity in which the curvature of the exTTF is closer to ligand $\mathrm{L} 1$. The new $\mathrm{M}_{6} \mathrm{~L}_{3}$ system has been fully characterized and exhibits electrochemical properties which are essentially similar to those of $\mathrm{M}_{4} \mathrm{~L}_{2}$, indicating that the strong $\pi$-donating ability of the cavity can be maintained while enlarging its size, and illustrating the high potential of the coordination-driven approach in tuning the size and the shape of a target cavity. This approach constitutes a promising strategy to address the design of organic materials (e.g. for organic photovoltaics or molecular electronic devices). Indeed, mastering the geometry of multicomponent redox-active systems offers a unique opportunity to fine-tuning electronic interactions within the material [43], an issue which is of prime importance for optimizing electron transport in organic materials.

\section{Supporting Information}

\section{Supporting Information File 1}

General methods, synthetic procedures, spectroscopic data. [http://www.beilstein-journals.org/bjoc/content/ supplementary/1860-5397-11-108-S1.pdf]

\section{Supporting Information File 2}

X-ray crystallographic data CCDC 1043205.

[http://www.beilstein-journals.org/bjoc/content/ supplementary/1860-5397-11-108-S2.cif]

\section{Acknowledgements}

The authors gratefully acknowledge the CNRS, the Région des Pays de la Loire and the MENRT for PhD grants (SB and VC), the PIAM (Univ. Angers) and the CRMPO (Univ. Rennes) technical platforms for their assistance in spectroscopic analyses. An access to the synchrotron Soleil - CRISTAL beamline - has been made possible (project 20130173); Drs Pierre Fertey and Sylvain Ravy are warmly acknowledged for their assistance. Finally, the Johnson-Matthey company is acknowledged for the generous providing of palladium salts.

\section{References}

1. Amouri, H.; Desmarets, C.; Moussa, J. Chem. Rev. 2012, 112, 2015-2041. doi:10.1021/cr200345v

2. MacGillivray, L. R. Angew. Chem., Int. Ed. 2012, 51, 1110-1112. doi:10.1002/anie.201107282

3. Chakrabarty, R.; Mukherjee, P. S.; Stang, P. J. Chem. Rev. 2011, 111, 6810-6918. doi:10.1021/cr200077m

4. Inokuma, Y.; Kawano, M.; Fujita, M. Nat. Chem. 2011, 3, 349-358. doi:10.1038/nchem.1031

5. Jin, P.; Dalgarno, S. J.; Atwood, J. L. Coord. Chem. Rev. 2010, 254, 1760-1768. doi:10.1016/j.ccr.2010.04.009

6. De, S.; Mahata, K.; Schmittel, M. Chem. Soc. Rev. 2010, 39, 1555-1575. doi:10.1039/b922293f

7. Therrien, B. Eur. J. Inorg. Chem. 2009, 2445-2453. doi:10.1002/ejic.200900180

8. Northrop, B. H.; Zheng, Y.-R.; Chi, K.-W.; Stang, P. J. Acc. Chem. Res. 2009, 42, 1554-1563. doi:10.1021/ar900077c

9. Stang, P. J. J. Org. Chem. 2009, 74, 2-20. doi:10.1021/j0801682d

10. Yoshizawa, M.; Klosterman, J. K.; Fujita, M. Angew. Chem., Int. Ed. 2009, 48, 3418-3438. doi:10.1002/anie.200805340

11. Han, Y.-F.; Jia, W.-G.; Yu, W.-B.; Jin, G.-X. Chem. Soc. Rev. 2009, 38 3419-3434. doi:10.1039/b901649j

12. Northrop, B. H.; Chercka, D.; Stang, P. J. Tetrahedron 2008, 64, 11495-11503. doi:10.1016/j.tet.2008.08.062

13. Northrop, B. H.; Yang, H.-B.; Stang, P. J. Chem. Commun. 2008, 5896-5908. doi:10.1039/b811712h

14. Cooke, M. W.; Chartrand, D.; Hanan, G. S. Coord. Chem. Rev. 2008, 252, 903-921. doi:10.1016/j.ccr.2008.01.006

15. Dalgarno, S. J.; Power, N. P.; Atwood, J. L. Coord. Chem. Rev. 2008, 252, 825-841. doi:10.1016/j.ccr.2007.10.010 
16. Zangrando, E.; Casanova, M.; Alessio, E. Chem. Rev. 2008, 108 4979-5013. doi:10.1021/cr8002449

17. Mukherjee, S.; Mukherjee, P. S. Chem. Commun. 2014, 50, 2239-2248. doi:10.1039/c3cc49192g

18. Mishra, A.; Kang, S. C.; Chi, K.-W. Eur. J. Inorg. Chem. 2013, 5222-5232. doi:10.1002/ejic.201300729

19. Cook, T. R.; Vajpayee, V.; Lee, M. H.; Stang, P. J.; Chi, K.-W. Acc. Chem. Res. 2013, 46, 2464-2474. doi:10.1021/ar400010v

20. Croué, V.; Goeb, S.; Sallé, M. Chem. Commun. 2015, 51, 7275-7289. doi:10.1039/C5CC00597C

21. Uehara, K.; Kasai, K.; Mizuno, N. Inorg. Chem. 2010, 49, 2008-2015. doi:10.1021/ic100011a

22. Ferrer, M.; Pedrosa, A.; Rodriguez, L.; Rossell, O.; Vilaseca, M. Inorg. Chem. 2010, 49, 9438-9449. doi:10.1021/ic101150p

23. Ghosh, S.; Mukherjee, P. S. Inorg. Chem. 2009, 48, 2605-2613. doi:10.1021/ic802254f

24.Sun, Q.-F.; Wong, K. M.-C.; Liu, L.-X.; Huang, H.-P.; Yu, S.-Y.; Yam, V. W.-W.; Li, Y.-Z.; Pan, Y.-J.; Yu, K.-C. Inorg. Chem. 2008, 47, 2142-2154. doi:10.1021/ic701344p

25. Yamamoto, T.; Arif, A. M.; Stang, P. J. J. Am. Chem. Soc. 2003, 125, 12309-12317. doi:10.1021/ja0302984

26. Fujita, M.; Sasaki, O.; Mitsuhashi, T.; Fujita, T.; Yazaki, J.; Yamaguchi, K.; Ogura, K. Chem. Commun. 1996, 1535-1536. doi:10.1039/cc9960001535

27. Maeda, H.; Akuta, R.; Bando, Y.; Takaishi, K.; Uchiyama, M.; Muranaka, A.; Tohnai, N.; Seki, S. Chem. - Eur. J. 2013, 19, 11676-11685. doi:10.1002/chem.201302028

28. Schweiger, M.; Seidel, S. R.; Arif, A. M.; Stang, P. J. Inorg. Chem. 2002, 41, 2556-2559. doi:10.1021/ic0112692

29. Goeb, S.; Bivaud, S.; Dron, P. I.; Balandier, J.-Y.; Chas, M.; Sallé, M. Chem. Commun. 2012, 48, 3106-3108. doi:10.1039/c2cc00065b

30. Holló-Sitkei, E.; Tárkányi, G.; Párkányi, L.; Megyes, T.; Besenyei, G. Eur. J. Inorg. Chem. 2008, 1573-1583. doi:10.1002/ejic.200701189

31. Weilandt, T.; Troff, R. W.; Saxell, H.; Rissanen, K.; Schalley, C. A. Inorg. Chem. 2008, 47, 7588-7598. doi:10.1021/ic800334k

32. Ferrer, M.; Gutiérrez, A.; Mounir, M.; Rossell, O.; Ruiz, E.; Rang, A.; Engeser, M. Inorg. Chem. 2007, 46, 3395-3406. doi:10.1021/ic062373s

33. Ferrer, M.; Mounir, M.; Rossell, O.; Ruiz, E.; Maestro, M. A. Inorg. Chem. 2003, 42, 5890-5899. doi:10.1021/ic034489j

34. Fang, Y.; Murase, T.; Sato, S.; Fujita, M. J. Am. Chem. Soc. 2013, 135, 613-615. doi:10.1021/ja311373f

35. Balandier, J.-Y.; Chas, M.; Goeb, S.; Dron, P. I.; Rondeau, D.; Belyasmine, A.; Gallego, N.; Sallé, M. New J. Chem. 2011, 35, 165-168. doi:10.1039/C0NJ00545B

36. Goeb, S.; Bivaud, S.; Croué, V.; Vajpayee, V.; Allain, M.; Sallé, M. Materials 2014, 7, 611-622. doi:10.3390/ma7010611

37. Vajpayee, V.; Bivaud, S.; Goeb, S.; Croué, V.; Allain, M.; Popp, B. V.; Garci, A.; Therrien, B.; Sallé, M. Organometallics 2014, 33, 1651-1658. doi:10.1021/om401142j

38. Bivaud, S.; Goeb, S.; Balandier, J. Y.; Chas, M.; Allain, M.; Sallé, M. Eur. J. Inorg. Chem. 2014, 2440-2448. doi:10.1002/ejic.201400060

39. Bivaud, S.; Goeb, S.; Croué, V.; Dron, P. I.; Allain, M.; Sallé, M. J. Am. Chem. Soc. 2013, 135, 10018-10021. doi:10.1021/ja404072w

40. Bivaud, S.; Balandier, J.-Y.; Chas, M.; Allain, M.; Goeb, S.; Sallé, M. J. Am. Chem. Soc. 2012, 134, 11968-11970. doi:10.1021/ja305451v

41. Cohen, Y.; Avram, L.; Frish, L. Angew. Chem., Int. Ed. 2005, 44, 520-554. doi:10.1002/anie.200300637
42. $M_{4} L_{2}$ presents an additional reversible redox system located at a higher potential $\left(\mathrm{Eox}=+0.80 \mathrm{~V}\right.$ vs $\mathrm{Fc} / \mathrm{Fc}^{+}$), corresponding to the reversible oxidation of the appended ferrocene $\mathrm{Pd}$ co-ligand.

43. Schneebeli, S. T.; Frasconi, M.; Liu, Z.; Wu, Y.; Gardner, D. M.; Strutt, N. L.; Cheng, C.; Carmieli, R.; Wasielewski, M. R.; Stoddart, J. F. Angew. Chem., Int. Ed. 2013, 52, 13100-13104. doi:10.1002/anie.201307984

\section{License and Terms}

This is an Open Access article under the terms of the Creative Commons Attribution License

(http://creativecommons.org/licenses/by/2.0), which permits unrestricted use, distribution, and reproduction in any medium, provided the original work is properly cited.

The license is subject to the Beilstein Journal of Organic Chemistry terms and conditions:

(http://www.beilstein-journals.org/bjoc)

The definitive version of this article is the electronic one which can be found at: doi:10.3762/bjoc. 11.108 